УДК 811.161.2'42:821.161.2-84

\title{
ПРИЙОМ РІЗНОПЛАНОВОЇ (КІЛЬКАПЛАНОВОЇ) АКТУАЛІЗАЦІЇ В АФОРИСТИЧНОМУ ТЕКСТІ
}

\author{
Жанна Колоїз \\ Криворізький державний педагогічний університет \\ Kryvyi Rih State Pedagogical University \\ пр. Гагаріна, 54, Кривий Ріг, 50086, Украӥна \\ koloiz.zv@gmail.com
}

\begin{abstract}
Колоїз Ж. Прийом різнопланової (кількапланової) актуалізації в афористичному тексті

У статті акцентовано на дискусійному характерові основних
\end{abstract} лінгвістичних параметрів афоризму; осмислено підходи до потрактування поняття “афористичний текст”. Наголошено на пошуках оригінальних механізмів актуалізації інтертекстуальних зв'язків і системних відношень, що пов'язано з актуалізацією як реалізацією потенційних властивостей мовних елементів у мовленні. Маніфестовано різнобій у витлумаченні понять "актуалізація" загалом та "подвійна актуалізація" зокрема. Запропоновано термін “різнопланова, або кількапланова, актуалізація”, яку кваліфіковано як індивідуально-авторський спосіб організації плану вираження, відбір та контамінація автоматизованих мовних засобів, які в одних і тих же контекстних умовах маніфестують різні (експліцитний та імпліцитний) смисли (план змісту), що, своєю чергою, сприяє створенню ефекту привабливості, викликає інтерес, захоплення, відкриває цікаві інтерпретувальні можливості.

Ключові слова: афоризм, афористичний текст, актуалізація, подвійна актуалізація, різнопланова (кількапланова) актуалізація, прийом, узуальні мовні засоби.

Колоиз Ж. Прием разноплановой (несколькоплановой) актуализации в афористическом тексте

В статье акцентируется внимание на дискуссионном характере основных лингвистических параметров афоризма; осмысливаются подходы к определению понятия “афористический текст". Исследуются поиски оригинальных механизмов актуализации интертекстуальных связей и системных отношений, что связано с актуализацией как реализацией потенциальных свойств языковых элементов в речи. Репрезентируется разнобой в толковании понятий “актуализация" в целом и “двойная актуализация” в частности. Предлагается термин “разноплановая, или несколькоплановая, актуализация”, который определяется как индивидуальноавторский способ организации плана выражения, отбор и контаминация 
автоматизированных языковых средств, которые в одних и тех же контекстуальных условиях манифестируют разные (эксплицитный и имплицитный) смыслы (план содержания), что, в свою очередь, способствует созданию эффекта привлекательности, вызывает воодушевление, восторг, увлечение, открывает интересные интерпретирующие возможности.

Ключевые слова: афоризм, афористический текст, актуализация, двойная актуализация, разноплановая (нескольколановая) актуализация, прием, узуальная языковые средства.

Koloiz Zh. The method of diverse (multifaceted) actualization in the aphoristic text

The method of diverse (multifaceted) actualization in the aphoristic text is comprehended in the article. Attention is drown to the problem questions of the modern aphoristic in common and determination of aphorism status. Discussion character of the main linguistic parameters of the aphorism is submitted in the paper. There are interpretation and separating of the categorical features, clarification of semantic, communicative, pragmatic, ethno-cultural peculiarities etc. Traditional terms such as "aphorism", "aphoristic unit", "aphoristic expression" and terms like "aphoristic genre", "aphoristic style", "aphoristic text", "aphoristic discourse" are represented. Trying to expand research aspects of the aphorisms from the linguistic text position is demonstrated in the article. The approaches to definition "aphoristic text" are found. These approaches are based on the specific interaction of content and expression; the presence of the main elements of communicative situation (sender $\rightarrow$ text $\rightarrow$ receiver).

The present paper concentrates on searching the original mechanism of actualization intertextual communications and system relationships for realization of pragmatic aim and reaching of cognitive-emotion effect. Such searching is connected with actualization like realization of the potential attributes of language elements in the speech. The article is manifested lack of coordination in the definition concept of "actualization" in general and "double actualization" in particular. The last is belonged mostly to the area of phraseology units' functioning. Aphorism authors use actualized linguistic means and usual (automatic) means in unusual (de-automatic) context surround, they unbalance the system of linguistic means for achievement of the communicative-pragmatic effect. Described unbalance happens in different ways, with using various linguistic-stylistic devices, among which so-called diverse or multifaceted actualization is distinguished.

Diverse actualization is interpreted as individually author's method of organization of the expression plan, as choice and contamination of automatic linguistic means that manifest different (explicit and implicit) meanings (content aspect) in the same context circumstance. It in turn helps to create the effect of attractiveness, arouses an interest and a delight and opens interesting interpretation possibilities. Special attention is paid to fact that usus linguistic means, which are attracted in the production process, manifest different level of the tension, the information saturation. But capable contamination of them within some aphorism certify appearance of "maximum intensity", that is based on interaction of literal and 
figurative, primary and secondary, denotative and connotative, free and bound senses etc.

Key words: aphorism, aphoristic text, actualization, double actualization, diverse (multifaceted) actualization, means, usus linguistic means.

Постановка проблеми та її зв'язок із важливими науковими завданнями. Донедавна одиниці, до категорійних ознак яких зараховують усталеність, відтворюваність, узагальненість, лаконічність, логічність, образність і т. ін., перебували в колі наукових зацікавлень здебільшого вченихфразеологів (М. Алексєєнко, М. Алефіренко, Н. Барлі, В. Бондаренко, А. Дандіс, Р. Дюплессі, А. Жолковський, В. Жуков, Є. Іванов, В. Калашник, Ж. Колоїз, А. Королькова, М. Котова, Г. Крейдлін, А. Крикманн, Т. Манякіна, В. Мокієнко, 3. Нойман, Г. Пермяков, Ю. Прохоров, Л. Савенкова, Л. Скрипник, Т. Стеффенс, Т. Радзісвська, В. Ужченко, Н. Шарманова та ін.). Однак вагомі здобутки як зарубіжної, так i вітчизняної фразеології сприяли виокремленню нової лінгвістичної царини - пареміології, об’єктом дослідження якої вважають пареміологічні одиниці, диференційовані на власне паремії й афоризми.

Нині можна 3 упевненість констатувати: вітчизняна пареміологія відбулася і як наука, і як навчальна дисципліна [Koloiz, Maliuha, Sharmanova / Колоїз, Малюга, Шарманова 2014]. Загалом випрацювано ii основні поняття, теоретично осмислено межі й обсяг одиниць, ідентифікованих як паремії, запропоновано ті чи ті підходи до систематизації розмаїтого паремійного матеріалу. Щоправда, наукова дискусія щодо проблем диференціації паремійного корпусу, його лінгвальної, філософської, концептуальної, етнокультурної, прагматичної і т. ін. специфіки продовжується. I це стосується не тільки (і не стільки!) власне паремій, до яких уналежнюють передовсім прислів'я й приказки, але й одиниць книжно-літературного походження - афоризмів, кваліфікованих як короткі влучні вислови, що передають узагальнену закінчену думку повчального або пізнавального змісту в лаконічно увиразненій формі [Ukrainska / Українська 2000 : 38]. Це лише одне з кількох десятків потрактувань, яке не претендує на 
загальноприйнятність, бо, як ми вже неодноразово зауважували в попередніх працях, “витлумачення поняття великою мірою залежить від того, з позицій якого аспекту воно розглядається і яким набором категорійних ознак характеризується відповідна лінгвоодиниця" [Koloiz / Колоїз 2014 : 213].

Дискусійний характер основних лінгвістичних параметрів афоризму (витлумачення, виокремлення категорійних ознак, з'ясування семантичних, комунікативно-прагматичних, етнокультурних особливостей i т. ін.) демонструє те, що афористична теорія, як i пареміологічна загалом, не $\epsilon$ викінченою, а відтак потребує більш детального, скрупульозного й комплексного вивчення.

До того ж поряд із репрезентацією й осмисленням (чи то переосмисленням!) традиційних термінів “афоризм”, “афористична одиниця”, “афористичне висловлення” в наукових доробках актуалізуються й терміни на зразок “афористичний жанр” (Г. Віват, О. Гриньків, О. Сгорова, Н. Карлик, Ю. Кобзєва, І. Кульганек, О. Машкіна, І. Наличникова, О. Самофалова та ін.), “афористичний стиль” (Є. Іванов, Г. Канакіна, Н. Тертична та ін.), “афористичний текст" (А. Авдєєва, О. Анастасьєва, Т. Водоватова, В. Дорда, Т. Манякіна та ін.), “афористичний дискурс" (М. Величко, Т. Тарасенко, О. Савельєва та ін.) тощо, які, своєю чергою, сприяли появі інших суперечливих моментів. Твердження про те, що афористичні висловлення варто зараховувати до особливого різновиду тексту зі своїми специфічними ознаками маніфестовано в багатьох доробках, однак, вочевидь, важко погодитися 3 думкою, згідно 3 якою до таких "характерних" ознак належать “відсутність фабули й текстового елемента заголовка, відсутність форм архітектоніки (початку, кінця, епіграфа, епілогу, сюжетної лінії) i хронотопу, наявність тенденції до появи нового смислу <..>, а також малої форми <..>” [Nalichnikova / Наличникова 2016 : 122-123]. У такому разі, напевне, доречніше було б говорити не про "характерні", а диференційні ознаки, що відрізняють афоризм від так званого класичного, насамперед художнього, тексту. Проблема ускладнюється й тим, що саме поняття тексту, як і афоризму, 
донині не отримало загальноприйнятого потрактування, а набір його категорійних ознак доволі строкатий. Звідси, відповідно, остаточно не розв'язана проблема зумовлює іншу. Це спостерігаємо й у підходах до з'ясування сутності термінологічного словосполучення “афористичний текст”, яке на сучасному етапі розвитку афористики так само отримало кілька дефініцій: на думку Є. Іванова, його можна тлумачити i як “вислів (зокрема й усталений), у якому виражена узагальнена й закінчена думка”, і як “будь-який текст, у якому наявні афоризми (й індивідуально-авторські, і загальномовні” [Ivanov / Иванов 2006:76]. Така позиція не забезпечила повного фундаментального вивчення проблеми, однак $\epsilon$ показовою спробою розширити аспекти дослідження афоризмів із погляду текстолінгвістики, або лінгвістики тексту.

Аналіз останніх досліджень та публікацій. Кількість наукових доробків, які актуалізують лінгвістичні аспекти дослідження афористичних текстів (висловлень), упродовж останніх десятиліть істотно змінилася [Vaganova / Ваганова 2002; Ivanov / Иванов 2016]. Цьому сприяло, з одного боку, прагнення з'ясувати лінгвістичну природу афоризму, а з іншого, - осягнути багатоплановість і багаторівневість організації тексту як лінгвістичної одиниці загалом [Bolotnolva / Болотнова 2009]. Якщо відштовхуватися від академічного потрактування тексту (“писемний або усний мовленнєвий масив, що становить лінійну послідовність висловлень, об’єднаних у ближчій перспективі смисловими і формально-граматичними зв'язками, а в загальнокомпозиційному, дистантному плані - спільною темою і сюжетною заданістю" [Ukrainska / Українська 2000 : 627]), то, цілком очевидно, що і смислова, i формальнограматична організація афоризмів мала б унеможливити їх зарахування до категорії текстових одиниць. Насправді ж непоодиноко натрапляємо на потрактування афоризму як малоформатного тексту (І. Наличникова), тексту малої форми (С. Землянська) і т. ін. У будь-якому разі науковці апелюють до суперечності між імпліцитним / експліцитним змістовим наповнення, оскільки вважають, що так званий “мініатюрний текст" є компресованим результатом індивідуально-авторського 
осмислення тих чи тих реалій об'єктивної (а подекуди - i вигаданої) дійсності, становить структурно-семантичну єдність, зумовлену взаємодією різних мовних рівнів [Zemlyanskaya / Землянская 2004 :9]. Аналіз семантичного простору (концептуального, денотативного, емотивного тощо) афористичного тексту здебільшого не викликає принципових заперечень: появу афоризму стимулює конкретна комунікативно-прагматична ситуація - комплекс зовнішніх умов спілкування, наявних у свідомості мовця в момент реалізації мовленнєвого акту: хто - що - де - коли - як - для чого - кому. Натомість, питання структурної організації (наприклад, реалізація таких ознак, як членованість, зв'язність і т. ін.) залишається відкритим і ще чекає на своє оригінальне розв'язання.

Мета запропонованої статті - осмислення прийому різнопланової (кількапланової) актуалізації в афористичному тексті як індивідуально-авторського способу відбору й контамінації автоматизованих мовних засобів задля створення ефекту привабливості.

Виклад основного матеріалу. Будь-яка афористична одиниця (чи то у статусі висловлення, чи то у статусі тексту) маніфестує специфічну взаємодією плану змісту й плану вираження: структурно-смислова цілісність передбачає завершеність як категорійну ознаку тексту, грунтовану на єдності імпліцитної початкової й експліцитної завершальної (узагальнювальної) частин, де перша - співвідносна 3 авторським задумом, а друга - підтверджує успішну реалізацію цього задуму. I як результат - складно організована система смислів, що відображають відповідну комунікативнопізнавальну ситуацію, пов'язану 3 авторською інтенцією, світоглядом, позицією, ціннісними орієнтирами, критичною оцінкою і т. ін. Наприклад: Про інших здебільшого говорять про себе (В. Ігнатенко); Проблеми столяра: на роботі знімають стружку, вдома - пиляють (Ю. Рибников); Продав чортові душу і облаштував райський куточок (Р. Крикун); Проспавши життя, пішов на вічний спочинок (Ю. Береза); Пропихають завжди те, щзо не лізе ні в які ворота (О. Шеремет) тощо. Такі

(с) Ж. Колоїз, 2019. 
афористичні зразки яскраво ілюструють наявність основних елементів комунікативної ситуації (адресант $\rightarrow$ текст $\rightarrow$ adpecam), мають лаконічну, придатну для запам'ятовування й подальшого відтворення форму, імпліцитний глибинний зміст, декодування якого відбувається у процесі сприйняття, усвідомлення, розуміння й інтерпретації авторських витворів, побудованих із добірного мовного матеріалу з використанням тих чи тих засобів і прийомів, що зазвичай взаємодіють, доповнюють, увиразнюють один одного. Афористи здебільшого вдаються до пошуку оригінальних механізмів актуалізації інтертекстуальних зв'язків і системних відношень задля реалізації прагматичної мети й досягнення когнітивноемоційного ефекту. У такому разі, зауважимо, ідеться про актуалізацію як про реалізацію “потенційних властивостей мовних елементів у мовленні” [Kocherhan / Кочерган 2003 : 416].

Однак термін “актуалізація" (від лат. actualis - дійсний, сучасний), як відомо, є багатозначним, засвідчує різнобій у витлумаченні навіть у межах однієї, скажімо, лінгвістичної царини. Пор.: “змістове й інтонаційне виокремлення мовних одиниць 3 певною комунікативною метою” [Dudyk / Дудик 2005 : 352-353]; “міграція питомої лексики або давно засвоєних запозичень від периферії до ядра лексичної системи" [Tuluzakova / Тулузакова 2015 : 92; Kovtunets / Ковтунець 2016 : 94-95; Struhanets / Струганець 2002 : 53-55]; “семантикостилістичне наголошення вільного і фразеологічно зв'язаного слова, порушення узвичаєних синтаксичних зв'язків у словосполученнях, реченнях, смислове виокремлення слова завдяки несподіваним асоціативним зв'язкам його 3 іншими поняттями" [Ukrainska / Українська 2000 : 14] і т. ін.

У науковому обігові відповідний термін з'явився завдяки працям представників Празького лінгвістичного гуртка (Б. Гавренек, Я. Мукаржовський), які, осмислюючи потреби й завдання літературної, зокрема й поетичної, мови, порушили питання, $з$ одного боку, про інтелектуалізацію мовних засобів, 3 іншого, - про їх автоматизацію й актуалізацію [Gavrenek / Гавренек 1967], де останню витлумачено як “щось незвичне у звичному мовленні”, як “використання мовних засобів, які 
привертають увагу самі по собі”, сприймаються як щось позбавлене автоматизму, [Gavrenek / Гавренек 1967], що виходить за межі традиційних схем, стандартів (“за допомогою автоматизації явища схематизуються, актуалізація ж означає порушення схеми" [Mukarzhovskiy / Мукаржовський 1967]).

Перефразовуючи Я. Мукаржовського, зауважимо: в афористичному тексті, який вирізняється знаковосеміотичною природою, характером вираження й способом сприйняття закодованої інформації, лінгвопрагматичною установкою і т. ін., репрезентує єдність поверхової й глибинної структур, актуалізація набуває "максимальної інтенсивності”. Це пов'язано передовсім із тим, що адресант, стимулюючи до розмірковувань, використовує відповідні зразки як знаряддя впливу на свідомість адресата, на корегування його поведінки відповідно до суспільних стереотипів, моральних норм, духовних цінностей тощо. Окрім того, афоризми як лінгвокультурні тексти малої форми розглядають i в координатах теорії прецедентності, крізь призму прецедентних феноменів, які наявні в національній когнітивній базі і які мають важливе значення для відображення специфіки національного менталітету й репрезентації мовної картини світу.

У такому разі, цілком закономірно, задля досягнення комунікативно-прагматичного ефекту афористи послуговуються актуалізованими мовними засобами, тобто використовують звичні (автоматизовані) засоби в незвичному (деавтоматизованому) контекстному оточенні. Інакше кажучи, виводять систему мовних засобів із “рівноваги", аби “сітка (система) відношень напружилася в певному напрямку і в такий спосіб внутрішньо організувалася" [Mukarzhovskiy / Мукаржовський 1967]. Ця внутрішня організація, згідно 3 позицією Я. Мукаржовського, залежить від домінанти, ключової ідеї, “пункту”, на якому роблять основний акцент. Порушення відповідної “рівноваги” відбувається по-різному, із використанням різних мовностилістичних прийомів, із-поміж яких вирізняється так звана різнопланова, або кількапланова, актуалізація (наразі активно використовуваним $\epsilon$ словосполучення “подвійна актуалізація”, рідше вживаними - 
терміни на зразок “буквалізація”, “дефразеологізація”, “семантична трансформація" тощо).

Теорію подвійної актуалізації розбудовували впродовж не одного десятка років, здебільшого у зв'язку з дослідженням фразеологічних одиниць у їх вузькому й широкому потрактуванні. Завдяки і зарубіжним, і вітчизняним науковцям “подвійна актуалізація" отримала статус прийому, грунтованого на подвійному сприйнятті тих чи тих мовних засобів у межах запропонованої ситуації, наприклад, обігравання значення фразеологічної одиниці та іï буквального прототипу (вільного (омонімічного) словосполучення).

3 огляду на найновіші лінгвістичні здобутки афоризми, як i власне паремії, є одиницями не фразеології, а пареміології i, будучи прецедентними феноменами, що маніфестують взаємодію прецедентних текстів, прецедентних ситуацій, прецедентних висловлень, подекуди і прецедентних імен, яскраво ілюструють реалізацію цього прийому, який має свою специфіку, у межах афористичних текстів. Наприклад: Росія $i$ Украӥна схожі, як дві пляшки мінералки, тільки одна з газом, а друга - без (А. Корчинський); Самозаглиблюватися - означає копати собі яму (В. Голобородько); Раніше сядеш - більше вип'єш (В. Титечко); Світ такий тісний, що постійно відчуваєш чужі руки у власних кишенях (Ф. Боднар); Серед твойх ворогів $\epsilon$ твій друг, а серед твоїх друзів - твій ворог (А. Закревський); Сильний показує зуби, а слабкий - язика (Н. Іванків); Скільки прислуги, зразу видно - слуга народу! (О. Перлюк) і т. ін. Кожен елемент того чи того афористичного тексту поза його межами сприймається як автоматизований, оскільки наявний у системі узуальних мовних засобів. Однак їх індивідуально-авторська контамінація в запропонованих зразках виводить цю систему 3 "рівноваги". У структурі афоризмів відбуваються переформатування компонентів, що спричиняє появу різновекторних відношень: у результаті ретельного відбору й спеціального розміщення тих чи тих мовних засобів автоматизація поступається деавтоматизації, що в наведених вище ілюстраціях виявляється у вигляді подвійної (чи то потрійної) актуалізації, як-от: Росія $i$ Украӥна схожі, як дві 
пляшки мінералки, тільки одна з газом, а друга - без (пор.: 3 одного боку, актуалізується значення лексеми газ - “газована, підкислена, шипуча, содова вода, у якій один або більше газів розчиняють природними чи штучними діями", 3 іншого, “блакитне паливо”); Самозаглиблюватися - означає копати собi яму (пор.: самозаглиблюватися - 1) “заглиблюватися в себе, у свій внутрішній світ, у свої почуття й переживання"; 2) “копати собі яму, тобто робити заглиблення, виймаючи, відкидаючи землю заступом, лопатою”; 3) "копати собі яму, тобто таємно готувати собі неприємність"; Скільки прислуги, зразу видно - слуга народу! (пор.: слуга народу - 1) “член органу державної влади, обраний народом”; 2) “президент” (актуалізує прецедентний текст - кінострічку “Слуга народу”); 3 ) “член однойменної партї”). Варто зауважити, що афоризм О. Перлюка (як і Л. Забари - Хочеш бути паном - стань слугою народу) 3'явився задовго до утворення партії “Слуга народу”, а тому третє значення 3'явилося на передньому плані недавно: нові реалії по-новому, в оригінальний спосіб вивели 3 "рівноваги" вже модифіковану сітку мовних засобів. Проілюстровані індивідуально-авторські зразки переконливо засвідчують: традиційний термін на зразок "подвійна актуалізація" лише частково відображає сутність аналізованого прийому, а відтак потребує нових підходів до осмислення.

Зважаючи на те, що будь-яка мовна одиниця має план вираження (форму) і план змісту (значення) і що у структурі афористичного тексту один і той же компонент (компоненти) може (можуть) одночасно актуалізувати кілька значень, цілком доречно, на нашу думку, такий прийом назвати різноплановою, або кількаплановою, актуалізацією. Це, по-перше, розширить сферу використання відповідного терміносполучення (виведе його за межі фразеологіi); по-друге, пов'язуватиме його не тільки $з$ фразеологізмами, а й з іншими мовними одиницями; потрете, дасть змогу апелювати не тільки до способів створення двоплановості, але й різноплановості, або кількаплановості. Наприклад: Розперезуються одні, а пояси затягують інші (Л. Забара); Совість у нього завжди чиста, бо ніколи не була в користуванні (Р. Крикун); Спускаючись службовою драбиною,

() Ж. Колоїз, 2019. 
ретельно перевіряйте якість перил (Ю. Рибников); Стріляючи очима, жінки не шкодують патронів, особливо холостих (Ф. Боднар); Ступивши на планету Земля, інопланетяни відразу ж відчули себе не в своїи тарілиі (А. Семенов); Схопити крадія за руку не пізно, навіть коли у нього все схоплено (В. Шамша); Ti, шуо вийшли на широку дорогу, починали колись із вузького провулка (Ф. Боднар); Там, де тупиюють на місиі, не виростає нічого (О. Домницький) і т. ін. Пор.: Розперезуються одні, а пояси затягують інші, де розперізуватися - “розв'язувати, розстібати на собі або знімати 3 себе пояс" і “ставати нестримним, свавільним, нахабним"; затягуватити пояс “обв'язуватися, підперізуватися поясом” і “обмежувати себе в їі, голодувати”. Процес декодування передбачає кілька варіантів, коли взаємодіють різні значення: 1) пряме + пряме; 2) пряме + переносне; 3) переносне + пряме; 4) переносне + переносне. Або: Совість у нього завжди чиста, бо ніколи не була в користуванні, де чиста совість - 1) “не забруднена, не замазана нічим; непідроблена, справжня”; 2) “усвідомлення кимось моральної відповідальності за свою поведінку, учинки перед самим собою, людьми і суспільством”; 3) “далека від безпосереднього практичного застосування, прямо не пов'язана 3 використанням"; 4) “звільнена від відповідальності за взяті на себе обов’язки, за справу, учинки, слова і т. ін.”. Відібрані для продукування афористичних текстів узуальні мовні засоби (план вираження) контамінуються в такий спосіб, який уможливлює актуалізацію експліцитних та імпліцитних смислів (план змісту).

Різнопланова, або кількапланова, актуалізація індивідуально-авторський спосіб організації плану вираження, відбір та контамінація автоматизованих мовних засобів, які в одних i тих же контекстних умовах маніфестують різні (експліцитний та імпліцитний) смисли (план змісту), що, своєю чергою, сприяє створенню ефекту привабливості, викликає інтерес, захоплення, відкриває цікаві інтерпретувальні можливості. Наприклад: Тим, хто обходить дев'ятою дорогою, заважають ті, у кого хата скраю (Ф. Боднар), де водночас актуалізуються прямі й переносні, зокрема і фразеологічно 
зумовлені, значення мовних одиниць: 1) “одні уникають зустрічей, не бажаючи мати ту чи ту неприємність, інші вважають, що певні події їх не стосуються, бо то не їхня справа"; 2) “ті, що намагаються не зачіпати нікого, рано чи пізно зіштовхуються 3 певними перепонами"; 3 ) “ухиляння від стосунків, розмов, зустрічей і т. ін. породжує незацікавленість, бездіяльність, байдужість”; 4) “байдужість залишається байдужістю, незалежно з якого богу ії розглядати” тощо. Інший приклад Товстий гаманець не шукає рещепта, як схуднути репрезентує і експліцитний, й імпліцитний плани змісту, як-от: 1) “наповнена, набита грішми шкіряна сумочка не шукає спосіб, як стати тоншою”; 2) “той, хто має велику суму грошей, велике багатство не потребує порад, вказівок, як зменшити його обсяги; 3) “власник великого капіталу переймається питаннями щодо його примноження”. Пор. також: Той, хто докопався до істини, часто не в змозі вилізти з ями (С. Скоробагатько); Той, кому постійно дивляться у рот, рідко його закриває (Л. Сухоруков); Той, у кого рот повний, заперечувати не буде (О. Домницький); Тяжко володіти собою, коли нічим іншим уже не володієш (В. Вовк); У безголових свої переваги. Принаймні, ніхто не сяде на голову (М. Левицький); Торговий парадокс: базар пташиний, ціни - собачі (Б. Слюсар); Тому $i$ запускають “качку”, щзо вона завжди зуміє вийти сухою з води (Ф. Боднар). Залучені у процес продукування узуальні мовні засоби маніфестують різний ступінь напруженості, інформаційної наснаженості, однак їх уміла контамінація в межах того чи того афоризму засвідчує появу “максимальної інтенсивності”, грунтованої на взаємодії прямих і переносних, первинних i вторинних, денотативних і конотативних, вільних і зв'язаних i т. ін. значень.

Афористичні тексти, порушуючи важливі проблеми сьогодення, засвідчують різні конфігурації способів і засобів різнопланової актуалізації, що мають на меті досягти бажаного ефекту - привернути увагу адресата до актуальної теми, долучити його іiі сприйняття, усвідомлення й декодування запропонованої інформації. Наприклад: Тонка натура всюди пролізе (Ф. Боднар) актуалізує мінімум два плани змісту:

(с) Ж. Колоїз, 2019. 
1) “людина, що має невеликий, незначний діаметр поперечного перерізу, мала в обхваті, спроможна, плазом або майже притискаючись до поверхні всім тілом, залізти будь-куди, навіть у вузький отвір, щілину, шпарку"; 2) “той, кому притаманна здатність швидко й легко розбиратися в людських стосунках, пристосовуючись і хитруючи, доб'ється вигідного соціального становища". Така різнопланова актуалізація демонструє взаємодію денотативно-конотативних значень. Пор.: У нас більшість живе потойбічним життям: по той бік межі бідності (Ф. Боднар), де потойбічне життя - 1) “неземне, загробне життя”; 2) “протилежне, відмінне від інших"; 3 ) “життя по той бік межі бідності"; У голодного - кама в голові (Ю. Рибников) репрезентує експліцитно-імпліцитний план змісту: 1) “той, хто відчуває голод, має гостре відчуття потреби в їжі, спроможний думати тільки про їжу”; 2) “той, хто відчуває голод, має гостре відчуття потреби в їжі, не здатний сприймати, оцінювати що-небудь правильно, реалістично, критично, розсудливо"; У правовому полі - свої бур'яни (Л. Забара) 1) “кожне поле засмічене бур'янами”; 2) “простір, у межах якого діє законодавство, так само заповнений чимось непотрібним, а подекуди й шкідливим”; 3) “серед фахівців із правознавства $є$ ті, які завдають йому шкоди, збитків”. Інтерпретація відображуваної дійсності вирізняється семантичною багатоплановістю, $є$ результатом контамінації різних неприхованих / прихованих значень узуальних мовних одиниць у межах конкретних ситуацій. У такому разі маємо змогу спостерігати навмисну (учинену свідомо, із певним наміром) інтенсифікацію змісту, транспозицію, модифікацію очікуваних уявлень про ті чи ті явища об'єктивної дійсності. Одна і та ж форма вираження здатна репрезентувати поверховий / глибинний, явний / прихований зміст, віддзеркалювати суб'єктивно оцінну й емоційну інформацію.

Цілком очевидно, що кожен автор афористичного тексту, продукуючи свій витвір, прагне відійти від стандартів, відхилитися від норми, аби уникнути нетривіальності, заяложеності, банальності, що, власне, й спонукає до виведення системи 3 “рівноваги", до пошуку оригінальних прийомів i 
засобів вираження (форми) й актуалізації змісту. Прийом різнопланової (кількапланової) актуалізації вирізняється структурно-семантичним розмаїттям i способів, i засобів, уналежнених до різних мовних рівнів і підрівнів. Наприклад: Третя сила може виявитися нечистою (Б. Ревчун); Чим менше ви важите, тим далі вас кинуть (Ф. Боднар); У людському суспільстві левина частка чомусь майже завжди дістається шакалам (С. Скоробагатько); $У$ житті, як у метро: одні піднімається, інші опускаються (В. Чемерис); У житті, як на довгій ниві: одні сіють, інші пожинають плоди (М. Левицький); У далеке зарубіжж їдуть або недалекі, або дуже близькі люди (В. Ігнатенко); Якщчо людині нічого не треба, значить, у неї чогось не вистачає (Р. Крикун); Якщо майбутнє за нами, то ие вже минуле (В. Момотюк) і т. ін. Відповідні зразки ілюструють “максимальну інтенсивність”, грунтовану на транспозиції змістових планів, що виникає в результаті незвичної структурної організації узуальних мовних засобів. I як результат - сприяє створенню “пружних емоційно-естетичних варіацій думки” (В. Чабаненко), збільшує виражальну силу афористичного тексту загалом, забезпечує потрібний експресивно-стилістичний ефект, посилює естетичний вплив на адресата, викликає в його уяві несподівані образи. Пор.: Щоб пізнати глибину, треба пірнути в наше болото (Ф. Боднар); Щоб тебе помітили, не обов'язково переходити комусь дорогу (О. Домницький); Якби не проблеми з джерелами енергії, ми не шукали б вітра в полі (Ф. Боднар); Якщо світло в кінці тунелю горить цілодобово, значить, виборна кампанія почалася (С. Коломієць). Чимало таких афоризмів засвідчує порушення валентності (семантичної / граматичної), подекуди репрезентує несумісні, контрастні, логічно не поєднувані речі, оскільки під час продукування афористичних текстів знімаються будь-які (структурно-формальні чи логіко-семантичні) обмеження. Завдяки актуалізація різних планів змісту в межах тієї чи тієї нестандартної ситуації відбувається, так би мовити, “збій у логіці мислення”, використання традиційних когнітивних стратегій критичного мислення повсякчас супроводжується тактиками творчого мислення, адже адресант порушує не лише

(c) Ж. Колоїз, 2019. 
мовні стереотипи, але й соціальні. Успішність комунікації залежить від адекватного сприйняття й усвідомлення запропонованої інформації, що, безумовно, залежить від віку, досвіду, інтелекту, фонових знань, мотивації, креативності і т. ін. адресата. Очевидним залишається i те, що у процесі продукування афористичного тексту адресант вдається до оновлення енергії узуальних мовних засобів (автоматизованих мовних знаків), “перезаряджає” їх для подальшого розряду.

\section{Висновки та перспективи подальших наукових} розвідок. Узагальнюючи, зауважимо: на сучасному етапі розбудови афористичної теорії залишається чимало дискусійних моментів, що стосуються основних лінгвістичних параметрів афоризму. Спостерігаємо прагнення науковців розширити аспекти дослідження афоризмів із позицій лінгвістики тексту, що слугувало підгрунтям для активізації поняття "афористичний текст”. Витлумачення відповідного поняття не викликає принципових заперечень, здебільшого репрезентує специфічну взаємодію плану змісту й плану вираження, яскраво ілюструє наявність основних елементів комунікативної ситуації, має лаконічну, придатну для запам'ятовування й подальшого відтворення форму, експліцитний (явний) та імпліцитний (прихований) змісти, декодування яких відбувається у процесі сприйняття, усвідомлення, розуміння.

Задля того, аби такі процеси мали успішну реалізацію, задля досягнення комунікативно-прагматичного ефекту, адресантові доводиться шукати певні механізми й прийоми, які вивели б систему звичних мовних засобів із “рівноваги”. Одним iз активно використовуваних прийомів в афористичному тексті $\epsilon$ різнопланова (кількапланова) актуалізація, що являє собою індивідуально-авторських спосіб структурної організації автоматизованих мовних засобів, які в конкретних контекстних умовах деавтоматизуються, маніфестуючи контамінацію різних експліцитних та імпліцитних смислів. Уважають, що така актуалізація засвідчує "максимальну інтенсивність", однак, гадаємо, ступенювання вияву інтенсивності, як і комплексне грунтовне осмислення особливостей виведених із "рівноваги" мовних засобів, потребує подальшого дослідження. 


\section{Література}

1. Болотнолва Н. С. Коммуникативная стилистика текста : словарьтезаурус. Москва : Флинта : Наука, 2009. 384 с.

2. Ваганова Е. Ю. Афоризм как тип текста в аспекте интертекстуальности: на материале немецкого языка: дис... канд. филол. наук : 10.02.04. Калининград, 2002. $261 \mathrm{c}$.

3. Гавренек Б. Задачи литературного языка и его культура. Пражский лингвистический кружск. Москва : Прогресс, 1967. С. 338-377. URL : https://sci.house/obschaya-lingvistika-scibook/gavranek-zadachi-literaturnogoyazyika-ego-106443.html

4. Дудик П. С. Стилістика української мови : навч. посіб. Київ : ВЦ “Академія”, 2005. 368 с.

5. Землянская Е. В. Структурно-семантические и функциональные особенности стилевой интертекстуальности в англоязычном афоризме : автореф. дис. ... канд. филол. наук : 10.02 .04 / Санкт-Петербургский государственный университет экономики и финансов. Санкт-Петербург, 2004. $18 \mathrm{c}$.

6. Иванов Е. Е. Лингвистика афоризма. Могилев : МГУ имени А. А. Кулешова, 2016. $156 \mathrm{c.}$

7. Иванов Е.Е. О понятиях “афористический текст”, “афористичность (афоризация) речи” и “афористический стиль”. Весиі Беларускага дзяржаўнага педагагічнага ўніверсітэта. Серия 1. Педагогіка. Псіхалогія. Філалогія. 2006. № 3 (49). C. 76-79. URL : https://libr.msu.by/bitstream/123456789/521/1/173m.pdf

8. Ковтунець О. Актуалізація як інноваційний процес у лексикосемантичній системі сучасної української літературної мови. Українська мова. 2016. № 3. C. 90-104. URL : http://nbuv.gov.ua/UJRN/Ukrm_2016_3_9

9. Колоїз Ж. В. Афоризми Ліни Костенко як транслятори загальнолюдських цінностей $\mathrm{i}$ національних пріоритетів. Філологічні студї : Науковий вісник Криворізького начіонального університету : зб. наук. праць. Кривий Ріг, 2014. Вип. 11. С. 210-232.

10. Колоїз Ж. В., Малюга Н. М., Шарманова Н. М. Українська пареміологія : навч. посіб. 2-е вид., стереотип. Кривий Ріг : ДВНЗ “КНУ”, 2014. 349 с.

11. Кочерган М. П. Загальне мовознавство : підручник. Київ : ВЦ “Академія”, 2003. 464 с.

12. Мукаржовский Я. Литературный язык и поэтический язык. Пражский лингвистический кружск. Москва : Прогресс, 1967. С. 406-431. URL : https://sci.house/obschaya-lingvistika-scibook/mukarjovskiy-literaturnyiy-yazyikpoeticheskiy-106446.html

13. Наличникова И. А. Афоризм как жанр, малоформатный текст и универсальное высказывание. Филологические науки. Вопросы теории и практики. Тамбов : Грамота, 2016. № 4 (58): в 3-х ч. Ч. 3. С. 121-123. URL : www.gramota.net/materials/2/2016/4-3/33.html

14. Струганець Л. В. Процеси актуалізації та пасивізації лексикосемантичних засобів в українській літературній мові кінця $\mathrm{XX}$ століття. Слово. Стиль. Норма : зб. наук. пр. Київ, 2002. С. 53-57. 
15. Тулузакова О. Г. Актуалізація лексики: стан дослідження проблеми. Наукові прачіЧорноморського державного університету імені Петра Могили. Серія : Філологія. Мовознавство. 2015. Т. 255. Вип. 243. С. 92-96. URL : http://nbuv.gov.ua/UJRN/Npchdufm_2015_255_243_19

16. Українська мова : Енциклопедія / редкол. В.М.Русанівський, О. О. Тараненко, М. П. Зяблюк та ін. Київ : Українська енциклопедія ім. М. П. Бажана, 2000. 750 с.

\section{References}

1. Bolotnolva N. S. Kommunikativnaya stilistika teksta : slovar-tezaurus. Moskva : Flinta : Nauka, 2009. $384 \mathrm{s.}$

2. Vaganova E. Yu. Aforizm kak tip teksta $\mathrm{v}$ aspekte intertekstualnosti: na materiale nemetskogo yazyika: dis... kand. filol. nauk : 10.02.04. Kaliningrad, 2002. $261 \mathrm{~s}$.

3. Gavrenek B. Zadachi literaturnogo yazyika i ego kultura. Prazhskiy lingvisticheskiy kruzhok. Moskva : Progress, 1967. S. 338-377. URL : https://sci.house/obschaya-lingvistika-scibook/gavranek-zadachi-literaturnogoyazyika-ego-106443.html

4. Dudyk P. S. Stylistyka ukrainskoi movy : navch. posib. Kyiv : VTs "Akademiia", 2005. $368 \mathrm{~s}$.

5. Zemlyanskaya E. V. Strukturno-semanticheskie i funktsionalnyie osobennosti stilevoy intertekstualnosti v angloyazyichnom aforizme : avtoref. dis. ... kand. filol. nauk : 10.02.04 / Sankt-Peterburgskiy gosudarstvennyiy universitet ekonomiki i finansov. Sankt-Peterburg, 2004. $18 \mathrm{~s}$.

6. Ivanov E. E. Lingvistika aforizma. Mogilev: MGU imeni A. A. Kuleshova, 2016. $156 \mathrm{~s}$.

7. Ivanov E. E. O ponyatiyah "aforisticheskiy tekst", "aforistichnost (aforizatsiya) rechi” i "aforisticheskiy stil". VestsI Belaruskaga dzyarzhay̆naga pedagagIchnaga y̆nIversIteta. Seriya 1. PedagogIka. PsIhalogIya. FIlalogIya. 2006. № 3 (49). S. 76-79. URL : https://libr.msu.by/bitstream/123456789/521/1/173m.pdf

8. Kovtunets O. Aktualizatsiia yak innovatsiinyi protses u leksyko-semantychnii systemi suchasnoi ukrainskoi literaturnoi movy. Ukrainska mova. 2016. № 3. S. 90-104. URL : http://nbuv.gov.ua/UJRN/Ukrm_2016_3_9

9. Koloiz Zh. V. Aforyzmy Liny Kostenko yak transliatory zahalnoliudskykh tsinnostei i natsionalnykh priorytetiv. Filolohichni studii : Naukovyi visnyk Kryvorizkoho natsionalnoho universytetu : zb. nauk. prats. Kryvyi Rih, 2014. Vyp. 11. S. 210-232.

10. Koloiz Zh. V., Maliuha N. M., Sharmanova N. M. Ukrainska paremiolohiia : navch. posib. 2-e vyd., stereotyp. Kryvyi Rih : DVNZ "KNU", 2014. 349 s.

11. Kocherhan M. P. Zahalne movoznavstvo : pidruchnyk. Kyiv : VTs “Akademiia", 2003. $464 \mathrm{~s}$.

12. Mukarzhovskiy Ya. Literaturnyiy yazyik i poeticheskiy yazyik. Prazhskiy lingvisticheskiy kruzhok. Moskva : Progress, 1967. S. 406-431. URL: https://sci.house/obschaya-lingvistika-scibook/mukarjovskiy-literaturnyiy-yazyikpoeticheskiy-106446.html 
13. Nalichnikova I. A. Aforizm kak zhanr, maloformatnyiy tekst i universalnoe vyiskazyivanie. Filologicheskie nauki. Voprosyi teorii i praktiki. Tambov : Gramota, 2016. № 4 (58): v 3-h ch. Ch. 3. S. 121-123. URL : www.gramota.net/materials/ 2/2016/4-3/33.html

14. Struhanets L. V. Protsesy aktualizatsii ta pasyvizatsii leksykosemantychnykh zasobiv v ukrainskii literaturnii movi kintsia KhKh stolittia. Slovo. Styl. Norma : zb. nauk. pr. Kyiv, 2002. S. 53-57.

15. Tuluzakova O. H. Aktualizatsiia leksyky: stan doslidzhennia problemy. Naukovi pratsiChornomorskoho derzhavnoho universytetu imeni Petra Mohyly. Seriia : Filolohiia. Movoznavstvo. 2015. T. 255. Vyp. 243. S. 92-96. URL : http://nbuv.gov.ua/UJRN/Npchdufm_2015_255_243_19

16. Ukrainska mova : Entsyklopediia / redkol. V. M. Rusanivskyi, O. O. Taranenko, M. P. Ziabliuk ta in. Kyiv : Ukrainska entsyklopediia im. M. P. Bazhana, 2000. $750 \mathrm{~s}$.

Стаття надійшла до редакиії 26.08.2019 p. Прийнята до друку 19.11.2019 p. 